\title{
ICT A Strategies for knowledge Empowerment of the Farmers
}

\author{
Richa Kumari and Arunima Kumari \\ Dr. Rajendra Prasad Central Agricultural University, Pusa, Samastipur, Bihar, India \\ *Corresponding author
}

\section{A B S T R A C T}

\begin{tabular}{|l|}
\hline K e y w o r d s \\
$\begin{array}{l}\text { Information and } \\
\text { Communication Technology } \\
\text { (ICT), Small land holder } \\
\text { farmers, Agricultural market } \\
\text { information, Market access } \\
\text { etc. }\end{array}$ \\
\hline Article Info \\
\hline $\begin{array}{l}\text { Accepted: } \\
\text { 06 May } 2018 \\
\text { Available Online: } \\
\text { 10 June } 2018\end{array}$ \\
\hline
\end{tabular}

\section{Introduction}

Information and Communication Technology is a revolutionary tool in recent decades which has impact on almost all fields of life. It is a well-known fact that ICT is very useful and efficient in Livestock Management, Veterinary hospitals management and Animal Diseases monitoring and Surveillance throughout the world. Information is power but the desired goal can be attained only when there is systematic dissemination or transfer of information. Information is the knowledge acquired through study, experience and instruction. Communication technology is the modality of disseminating the information to the targeted population. The cost involved in face-to-face information dissemination at the right time and the difficulties of reaching the target audiences have also created the urgency to introduce ICT for this purpose. It is only through the introduction of ICT that information can also be updated and extended at the lowest cost. Any communication technology can survive better when it has more reach, readability, reliability, rapidity and readiness to be used. In this era of globalization, Information and Communication Technology (ICT) has become a powerful tool for improving the delivery service and enhancing local development opportunities (Gorstein, 2003). Sustainable prosperity of the farmers and the agricultural labourers holds the key for improving the overall human resource development scenario in the country. There is 
a need to increase production and productivity of agriculture. Hence, the Indian farmers need to be updated with the latest knowledge about new techniques of farming, new cultivars, farm machinery, market and trade situation etc. Rural Communities require information on supply of inputs, new farming technologies, early warning of natural disasters, credit, market price and their competition. Such information knowledge, technology and service contribute to expanding and energizing agriculture (Munya, 2000).

Now days the penetration of market forces in rural India is increasing and is potential market. With the diverse cultures and languages in India, ICT provides a good platform here. Thus in future there would be substantial upliftment and sustainable development in rural areas.

\section{Materials and Methods}

The study was carried out in Samastipur district of Bihar state. The population for the study comprises of two blocks farmers in the study area. A total of 80 farmers were randomly selected from 4 villages based on proportion of the respondents in each village. A structured and validated interview schedule was used to collect relevant information from the sampled respondents. Descriptive statistical tools used in the data analysis include: frequency, percentages, mean and standard deviation.

\section{Results and Discussion}

Knowledge about any technology is a prerequisite for adoption. An attempt has been made to study the knowledge of respondents about ICTs in the field of agriculture.

It is evident from the Table 1(i) and (ii) that out of 80 respondents, among progressive farmers 22.5 per cent have medium level of knowledge, 10 per cent have low level of knowledge and 67.5 per cent having high level of knowledge (Fig. 1).

Further, among non-progressive farmers 47.5 per cent have medium level of knowledge, 22.5 per cent have low level of knowledge and 30 per cent having high level of knowledge.

Table.1 (i) Distribution of respondents (progressive farmers) into different categories with respect to the knowledge levels

\begin{tabular}{|c|l|c|c|}
\hline Sl. & \multicolumn{1}{|c|}{ Knowledge Level } & \multicolumn{2}{|c|}{ Progressive farmers (40) } \\
\cline { 3 - 4 } No. & & Frequency & Percentage \\
\hline $\mathbf{1}$ & Low (0.00-87.13) & 4 & 10 \\
\hline $\mathbf{2}$ & Medium(87.13-99.19) & 9 & 22.5 \\
\hline $\mathbf{3}$ & High(99.19 and above) & 27 & 67.5 \\
\hline & Total & $\mathbf{4 0}$ & $\mathbf{1 0 0}$ \\
\hline
\end{tabular}

Mean $=93.13$, S.D $=6.06$ 
Table.1 (ii) Distribution of respondents (non-progressive farmers) into different categories with respect to the knowledge levels

\begin{tabular}{|c|c|c|c|}
\hline $\begin{array}{c}\text { Sl. } \\
\text { No. }\end{array}$ & Knowledge level & \multicolumn{2}{|c|}{ Non-progressive farmers (40) } \\
\hline $\mathbf{1}$ & & Frequency & Percentage \\
\hline $\mathbf{2}$ & Low $(0.0-76.91)$ & 9 & 22.5 \\
\hline $\mathbf{3}$ & Medium(76.9 -98.53) & 19 & 47.5 \\
\hline & High(98.53 and above $)$ & 12 & 30 \\
\hline
\end{tabular}

Mean $=87.72$, S.D $=10.81$

Fig.1 Distribution of respondents among different categories with respect to the knowledge levels

Progressive Farmers

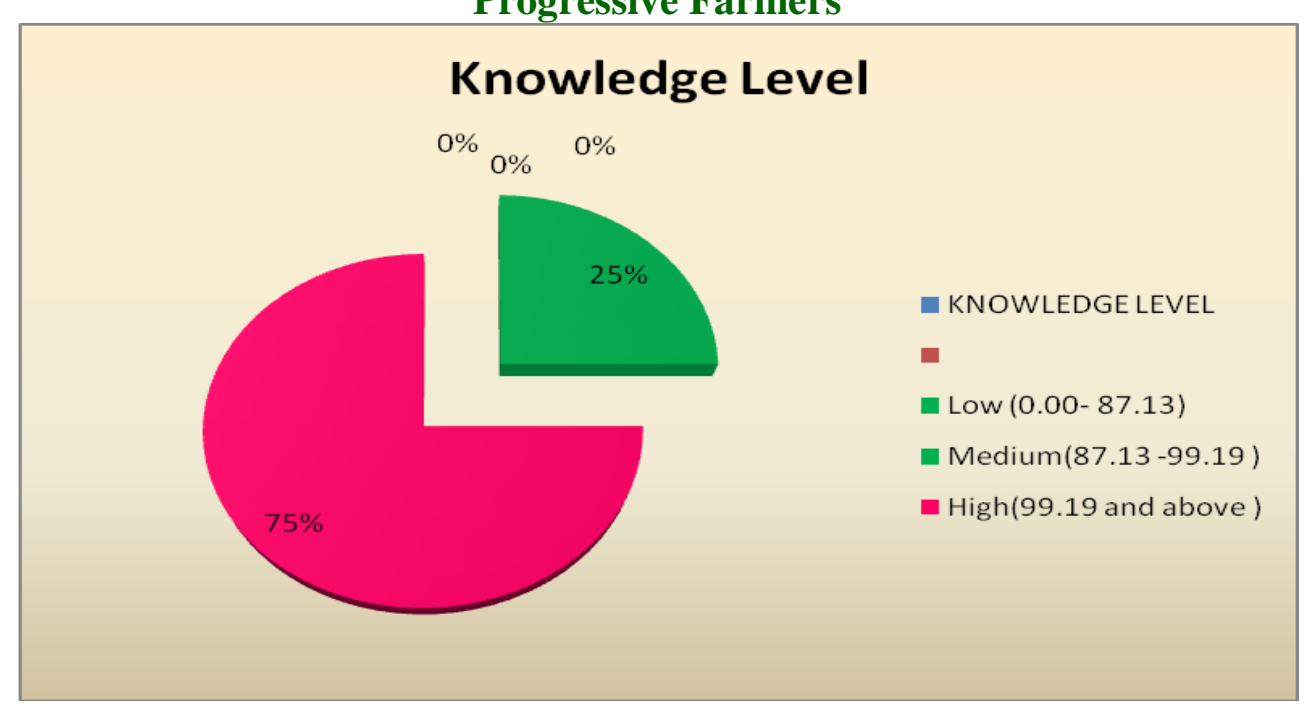

Non-progressive Farmers

\section{Knowledge Level}

KNOWLEDGE LEVEL

Low $(0.00-76.91)$

Medium(76.91 -98.53) High (98.53 and above )

$0 \% 0 \%$

$30 \% \quad 22 \%$

$48 \%$ 
Based on the findings of the study the following conclusions were drawn. Knowledge is important to farmers to undertake their day to day agricultural activity and also benefits them to have up-to-date information in all aspects and makes them to be competent and productive and ICTs contribution in this regard is very high.

ICTs are changing all the spheres of human lives and agriculture cannot be an exception. ICTs now may act as an agent for changing agrarian and farmer's life by improving access of information and sharing knowledge. The ICT tools can change the ideas, activities and knowledge of the farmers. Farmers feel empowered and can adopt appropriate measures at the time of need.

\section{References}

Gurstein M. 2003. Effective Use: A Commonly Informatics Strategy Beyond the Digital Divide. Pakistan Academy for Rural Development, Peshaawa. Pp 259-269.

Munya, U. 2000. Information and Communication Technologies for Rural Development and Food Security: Lessons from Field Experience in Developed Countries. Sustainable Development FAO. Rose, Pp. 1-12.

\section{How to cite this article:}

Richa Kumari and Arunima Kumari. 2018. ICT A Strategies for knowledge Empowerment of the Farmers. Int.J.Curr.Microbiol.App.Sci. 7(06): 1250-1253.

doi: https://doi.org/10.20546/ijcmas.2018.706.147 